\title{
Comparison between eletrosurgery and cold blade in tongues of rats. A preliminary experimental study ${ }^{1}$
}

\author{
Estudo comparativo entre eletrocirurgia e bisturi frio em língua de ratos. Estudo preliminar \\ experimental
}

\author{
Belmiro Cavalcanti do Egito Vasconcelos ${ }^{\mathrm{I}}$, Lígia Helena Macedo de Freitas ${ }^{\mathrm{II}}$, Luciana Karla de Morais Santos ${ }^{\mathrm{II}}$, José Ricardo \\ Dias Pereira $^{\mathrm{III}}$, Riedel Frota ${ }^{\mathrm{IV}}$, Gabriela Granja Porto ${ }^{\mathrm{V}}$ \\ ${ }^{\mathrm{I}} \mathrm{PhD}$, Full Professor, Department of Oral and Maxillofacial Surgery. Coordinator of the PhD Program in Oral and Maxillofacial Surgery, UFPE, Recife, \\ Brazil.

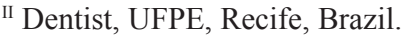 \\ III $\mathrm{PhD}$, Full Professor, Department of Pathology, UFPE, Recife, Brazil. \\ Iv $\mathrm{PhD}$, Dentist, UFPE, Recife, Brazil. \\ ${ }^{v}$ Master, Department of Oral and Maxillofacial Surgery, UFPE. Fellow PhD degree, Program in Oral and Maxillofacial Surgery, UFPE, Recife, Brazil.
}

\begin{abstract}
Purpose: To compare tissue cicatrization in the tongue of rats using electrosurgery and the cold blade. Methods: Ten adult male Wistar rats were divided into two groups of 5 animals each, according to the time of sacrifice ( 3 and 7 days). Each animal had two incisions, one made with a cold blade and the other with an electric blade, both of which were approximately $0.5 \mathrm{~mm}$ in length. Following sacrifice of the animals, the tongues were submitted to a histological study in order to classify the presence of angiogenesis, fibroblastic proliferation, epithelial proliferation and inflammatory cells as good, moderate and weak. Results: The wound made with electric blade presented a delay in the healing process and a greater inflammatory response as compared with the cold blade, despite the fact that there was no statistically significant difference $(\mathrm{p}<0.05)$. Conclusion: There were no significant statistical differences between electrosurgery and the cold blade in relation to angiogenesis, fibroblastic proliferation, epithelial proliferation or the presence of inflammatory cells at any time of evaluation.
\end{abstract}

Key words: Electrosurgery. Wound Healing. Tongue. Rats, Wistar.

\section{RESUMO}

Objetivo: Comparar a cicatrização tecidual com bisturi elétrico e frio em língua de ratos. Métodos: A amostra foi de 10 ratos Wistar, divididos em dois grupos com 5 animais em cada, de acordo com o tempo de sacrifício ( 3 e 7 dias).Cada animal teve duas incisões transversais, com $0,5 \mathrm{~mm}$ de comprimento, no dorso da língua, sendo a mais anterior com a eletrocirurgia (experimento), e a mais posterior, com bisturi convencional (controle). Após o sacrifício dos animais, as línguas foram submetidas a análise histológica para classificação da presença de angiogeneses, proliferação fibroblástica e epitelial e células inflamatórias em boa, moderada e fraca. Resultados: Os resultados indicaram que as feridas realizadas com bisturi elétricos apresentaram um retardo no processo cicatricial e uma maior resposta inflamatória quando comparadas com as feridas do bisturi frio, apesar de não ter havido diferença estatisticamente significante $(\mathrm{p}<0.05)$. Conclusão: Não houve diferença significante entre o bisturi elétrico e frio em relação a presença de angiogeneses, proliferação fibroblástica e epitelial e células inflamatórias para nenhum dos dois tempos de avaliação.

Descritores: Eletrocirurgia. Cicatrização de Feridas. Língua. Ratos Wistar.

${ }^{1}$ Research performed at Postgraduate Program in Oral and Maxillofacial Surgery, University of Pernambuco (UFPE), Recife, Brazil.

\section{Introduction}

Electrosurgery is a surgical intervention that uses electricity or, more accurately, high-frequency electrical currents to achieve its goal ${ }^{1}$. These high-frequency electrical currents employed in electrosurgery exceed $100 \mathrm{KHz}$, the most commonly used ones being those that oscillate between $2 \mathrm{mHz}$ and $4 \mathrm{mHz}$. This type of frequency has the advantage of not producing any of the harmful effects observed with exposure to low-frequency electrical currents, such as neuromuscular excitation, ventricular fibrillation and burns, since it causes only localized deformations. The electric blade, an electronic apparatus that generates this type of current, allows us, among other uses, to staunch minor bleeding, incise and dissect tissues, resect tumors and treat fissures ${ }^{2,3}$. However, electrocautery may also cause complications: burns, electromagnetic interference with other instruments in the operating suite, produce a smoke plume; and finally affect pacemakers, implanted cardiac devices, and cochlear implants that 
may malfunction during use of electrocautery ${ }^{4,5,6}$. Moreover the electrosurgery can not be used for tissue excision in oral biopsy leads to tissue destruction that hinders its later histopathologic examination. For this reason this technique is not recommended for biopsies ${ }^{5,6,7}$.

Although the medical literature abounds in studies on the use of electrosurgery, there continues to be a dearth of studies on the advantages offered by electrosurgery in the treatment of inflammatory, hyperplastic or neoplastic diseases of the oral cavity $^{8}$. This being so, the present paper sets out to compare the cicatrization of the mucosa of rat tongues following incisions made by electrosurgery with that resulting from the use of the cold blade.

\section{Methods}

Ten male adult Wistar rats were used for the experiment. The trial protocol was approved by the Pernambuco University's Ethics Committee. The rats were divided into two groups of 5 animals each, according to the time of sacrifice ( 3 and 7 days). The same animal had two incisions. The first one was made by the cold blade placed in the posterior region of the tongue and the other was made using the electric blade and was placed in the anterior region of the tongue, both incisions being approximately $0.5 \mathrm{~mm}$ in length.

All animals were subjected to surgery under general anesthesia, which was induced by muscular injection of ketamine and xylazine diluted $1: 1$ in a dose of $0.1 \mathrm{ml}$ per $100 \mathrm{~g}$ of weight. For local anesthesia $0.2 \mathrm{ml}$ of lidocaine (1:200.000) was infiltrated. For better exposure of the incisions, traction of the tongue was done with 4-0 silk thread on the tip of the rat's tongue.

In the cold blade incisions \#15 blades were used, while in the electrosurgical ones the apparatus used was the KVN BE-02 at a $7 \mathrm{MHz}$ duly modulated highfrequency current (totally rectified and filtered) in accordance with the manufacturer's recommendations. All the incisions cicatrized by second intention, no suture having been used for drawing together the edges of the wound in any of the animals.

After sacrifice of the rats at 3 and 7 days, the tongues were submitted to histological study in order to classify the presence of angiosenesis, fibroblastic proliferation, epithelial proliferation and inflammatory cells as good, moderate or weak.

The specimens were fixed in $10 \%$ formol. Semi-serial sections $5 \mu \mathrm{m}$ thick were cut in the sagittal plane and stained with hematoxylin and eosin.
The statistical analysis consisted of the comparison of proportions obtained in related samples (McNemar tests of marginal homogeneity) and in independent samples (FisherFreeman-Halton test). The 0.05 level of significance was adopted for each test.

\section{Results}

Histopathologically, in relation to the angiogenesis, the experimental group (electrosurgery) was classified as good at 3 days of postoperative evaluation and as moderate at 7 days (Figure 1 and Table 1). The control group (cold blade) was classified as good in $40 \%$ of the cases, as moderate in the other $40 \%$ and as weak in $20 \%$ of the animals at 3 days of postoperative evaluation. At 7 days of evaluation of the control group the angiogenesis was classified as moderate in $75 \%$ and as weak in $25 \%$ of the animals (Figure 2 and Table 1).

In relation to the fibroblastic proliferation, the experimental group at 3 days of evaluation was classified as moderate in $50 \%$ of the cases and as weak in the other $50 \%$, and at the same time of evaluation the control group was classified as good in $20 \%$ of the cases and as moderate in $80 \%$ (Figure 3 and Table 1). At 7 days of evaluation, the experimental group was classified as moderate in $60 \%$ of the animals and as weak in $40 \%$ (Figure 4 ) and the control group was classified as moderate in $25 \%$ and as weak in $75 \%$ of the animals (Figure 2 and Table 1).
TABLE 1 - Classification of angiogenesis and fibroblastic proliferation according to the use of electrosurgery and cold blade at 3 and 7 days of evaluation

\begin{tabular}{lcccc}
\hline & \multicolumn{2}{c}{3 days } & \multicolumn{2}{c}{7 days } \\
& Cold blade & Electrosurgery & Cold blade & Electrosurgery \\
\hline Angiogenesis & $1(20 \%)$ & 0 & $1(25 \%)$ & 0 \\
Weak & $2(40 \%)$ & 0 & $3(75 \%)$ & $5(100 \%)$ \\
Moderate & $2(40 \%)$ & $4(100 \%)$ & 0 & 0 \\
Good & $5(100 \%)$ & $4(100 \%)$ & $4(100 \%)$ & $5(100 \%)$ \\
Total & $p^{1}=0.50$ & $p^{1}=1.00$
\end{tabular}

\begin{tabular}{lcccc}
\hline \multicolumn{4}{l}{ Fibroblastic proliferation } \\
Weak & 0 & $2(50 \%)$ & $3(75 \%)$ & $2(40 \%)$ \\
Moderate & $4(80 \%)$ & $2(50 \%)$ & $1(25 \%)$ & $3(60 \%)$ \\
Good & $1(20 \%)$ & 0 & 0 & 0 \\
Total & $5(100 \%)$ & $4(100 \%)$ & $4(100 \%)$ & $5(100 \%)$ \\
p value & $p^{1}=0.250$ & $p^{1}=0.250$
\end{tabular}




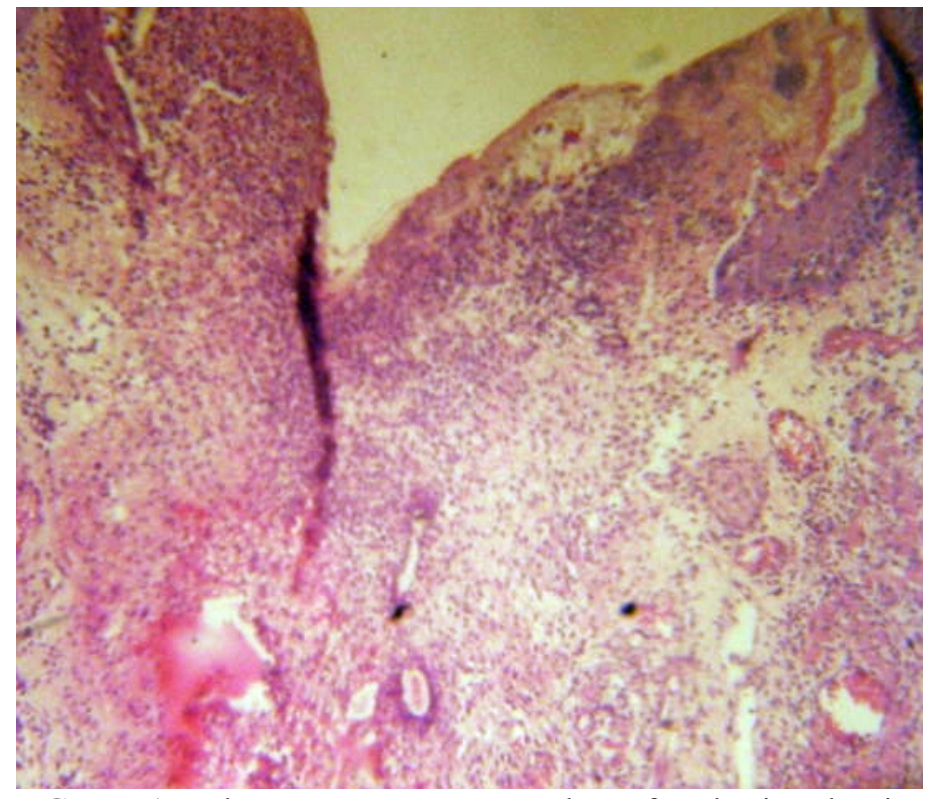

FIGURE 1 - Electrosurgery group at 7 days of evaluation showing angiogenesis, fibroblastic proliferation and the presence of inflammatory cells (H\&E 10X)

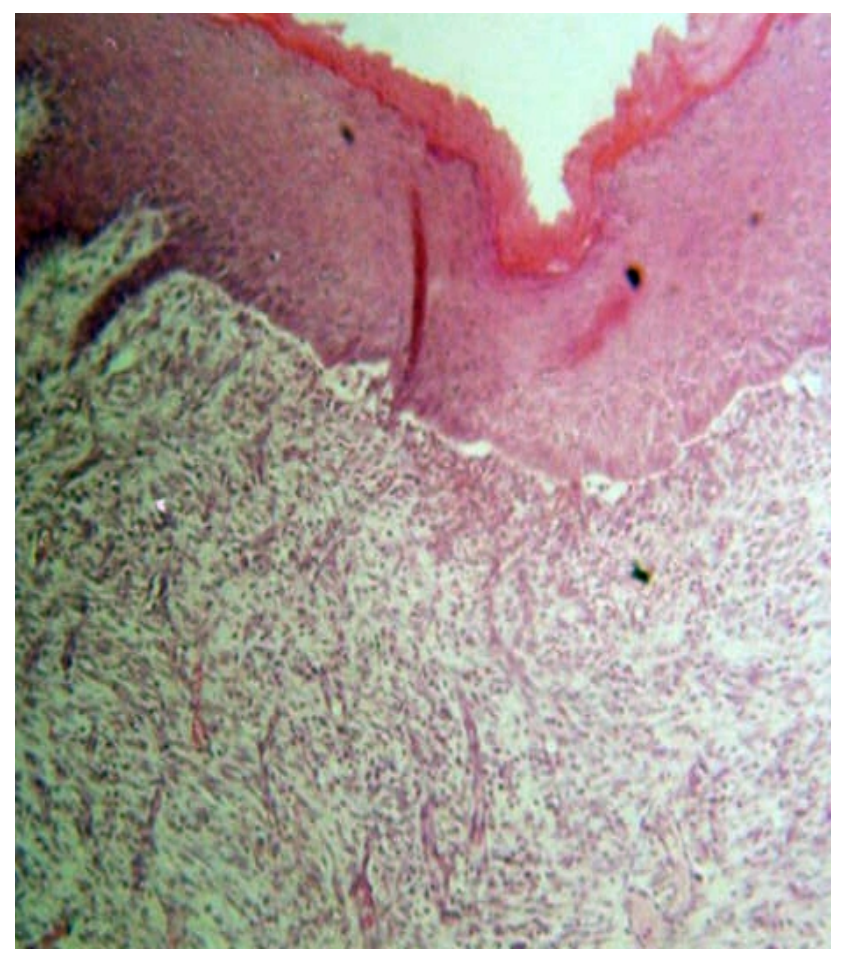

FIGURE 2 - Cold blade group at 7 days of evaluation showing angiogenesis, fibroblastic and epithelial proliferation and presence of inflammatory cells (H\&E 10X)

In relation to the epithelial proliferation, the experimental group (electrosurgery) was classified as moderate in $25 \%$ of the animals, as weak in $25 \%$ and as absent in $50 \%$ at 3 days of postoperative evaluation and as weak in $25 \%$ of the cases and as absent in $75 \%$ at 7 days (Table 2). The control group (cold blade) was classified as good at 3 days of postoperative evaluation. At 7 days of evaluation of the control group the proliferation was classified as good in $25 \%$, as weak in $75 \%$ and as absent in $25 \%$ of the animals (Figure 2 and Table 2).

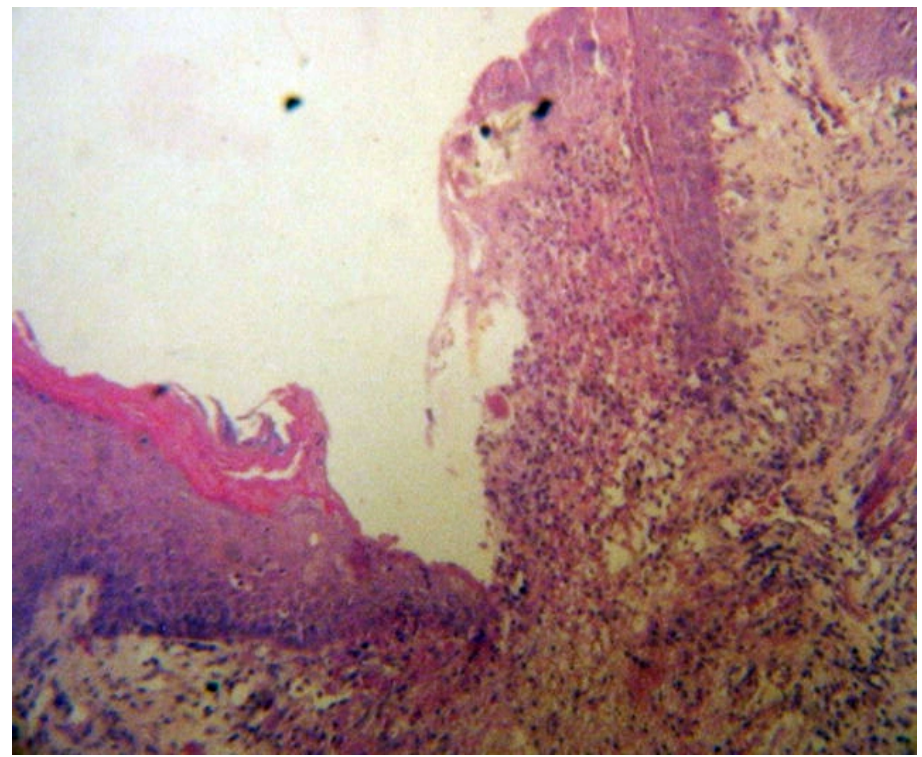

FIGURE 3 - Cold blade group at 3 days of evaluation showing a fibroblastic proliferation and the presence of inflammatory cells (H\&E 10X)

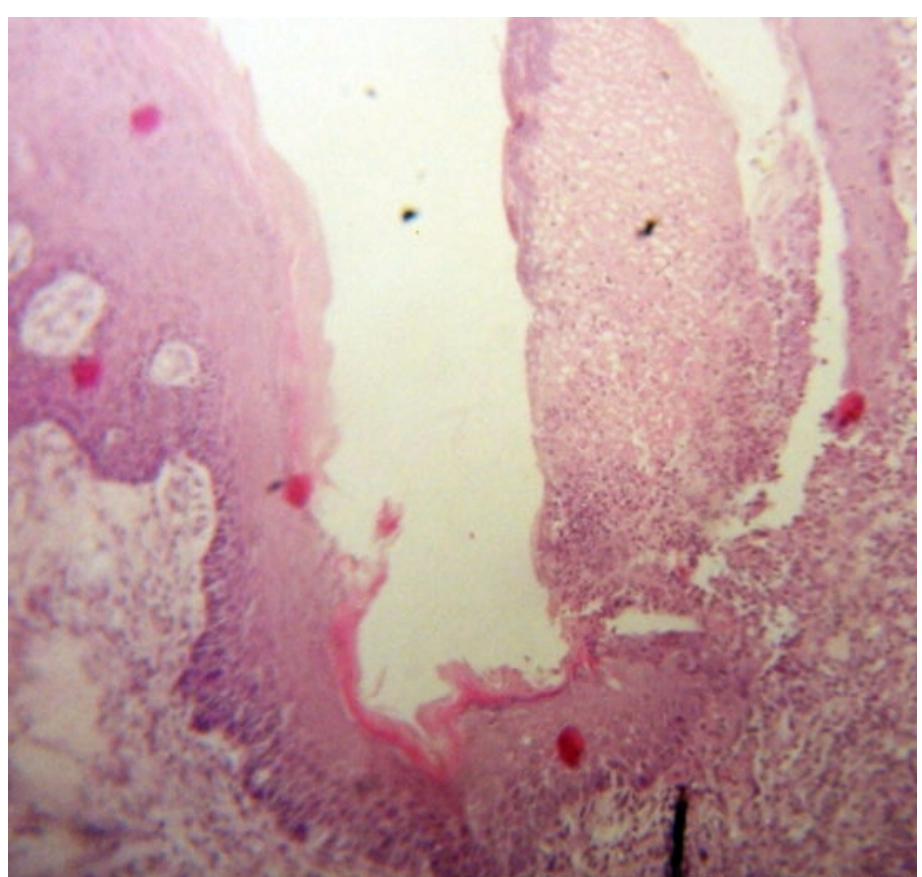

FIGURE 4 - Electrosurgery group at 3 days of evaluation showing fibroblastic proliferation and the presence of inflammatory cells (H\&E 10X)

In relation to the presence of inflammatory cells, the experimental group at 3 days of evaluation was classified as good in $75 \%$ of the cases and as moderate in the other $50 \%$ (Figure 4), and at the same time of evaluation the control group was classified as good in $20 \%$ of the cases, as moderate in $40 \%$ and as weak in the other $40 \%$ (Table 2). At 7 days of evaluation, the experimental group was classified as good in $75 \%$ of the animals and as moderate in $25 \%$ (Figure 1) and the control group was classified as moderate in $50 \%$ and as weak in $50 \%$ of the animals (Figure 2 and Table 2). 
TABLE 2 - Classification of epithelial proliferation and inflammatory cells according to the use of electrosurgery and cold blade at 3 and 7 days of evaluation

3 days 7 days

\section{Cold blade Electrosurgery Cold blade Electrosurgery}

\section{Epithelial proliferation}

\begin{tabular}{lcccc} 
Absent & 0 & $2(50 \%)$ & $1(25 \%)$ & $3(75 \%)$ \\
Weak & 0 & $1(25 \%)$ & $2(50 \%)$ & $2(25 \%)$ \\
Moderate & 0 & $1(25 \%)$ & 0 & 0 \\
Good & $5(100 \%)$ & 0 & $1(25 \%)$ & 0 \\
Total & $5(100 \%)$ & $4(100 \%)$ & $4(100 \%)$ & $5(100 \%)$ \\
p value & \multicolumn{2}{c}{$p^{1}=0.125$} & $p^{1}=0.250$
\end{tabular}

\section{Inflammatory cells}

\begin{tabular}{lcccc} 
Weak & $2(40 \%)$ & 0 & $2(50 \%)$ & 0 \\
Moderate & $2(40 \%)$ & $1(25 \%)$ & 0 & $1(25 \%)$ \\
Good & $1(20 \%)$ & $3(75 \%)$ & $2(50 \%)$ & $4(75 \%)$ \\
Total & $5(100 \%)$ & $4(100 \%)$ & $4(100 \%)$ & $5(100 \%)$ \\
p value & \multicolumn{2}{c}{$p^{1}=0.375$} & $p^{1}=0.250$
\end{tabular}

$1=$ McNemar Test

\section{Discussion}

Electrosurgery has many applications in all fields of dentistry, although this technique is not widely used. Inconsistencies in the reports of the cicatrization of electrosurgical wounds may be attributed to the lack of standardization of the factors involved in electrosurgery, owing to the fact that, when these factors are controlled, no clinically or histologically significant differences can be seen between the cicatrization resulting from the electrosurgical wound and that produced by the cold blade $e^{9,10,11}$, which is commonly employed because of its ease of use, accuracy, and minimal damage to tissues. However, scalpels do not provide a good hemostasis, which is important on highly perfused tissues such as in the oral cavity ${ }^{12}$.

A study made in 1988 compared the effects of electrosurgery and cold blade in the cicatrization in human incisions using electronic microscopy. No statistically significant differences were found and all the surgical wounds were seen to have healed within 7 days $^{13}$. The results of the present study agree with those of 1988 study, as there were no significant statistical differences for the variables studied at 3 and 7 days of evaluation.

In other study ${ }^{4}$ the authors compared wounds caused by cold blade, cryosurgery, electrocautery, and $\mathrm{CO}_{2}$ laser in incisions on the tongue of rats. They demonstrated that the wounds inflicted with a steel scalpel healed faster than those caused by any of the other techniques, probably because the nearness (all the wounds made with steel scalpel alone were sutured) of the wounds, edges aids rapid reepithelialization.

Migliosi ${ }^{14}$ observed a tendency for cicatrization to be delayed with the use of electrosurgery, as compared with the cold blade, when angiogenesis, fibroblastic proliferation, epithelial proliferation and inflammatory cells were noted, albeit without any statistically significant differences. From a descriptive standpoint ${ }^{14}$, with electrosurgery the delay in cicatrization was longer, the inflammatory response more intense and the destruction of the tissue greater than with the cold blade.

In a study involving gingival incisions it was noted that the initial response of the connective tissue is different when electrosurgery is used. Following careful control of the electrosurgical procedures, a small area of denaturalization, produced by lateral heat, is always found in the trajectory adjacent to the incision. This area did not appear to affect the the stages of cicatrization of the wound and usually disappears over a period of two weeks ${ }^{15}$. The immediate response of the connective tissue was not evaluated in this study, although at 3 days there was less fibroblastic proliferation in the electrosurgery group.

Charbeneau and Stephenson ${ }^{16}$ stated that electrosurgery was regarded as a safe and effective method, and when used correctly did not cause any major damage to the periodontal tissue, when compared to the cold blade, despite causing necrosis by virtue of the coagulation separating the tissue from the neighborhood of the electrode. In wounds of this nature, complete cicatrization is believed to occur, albeit in a slower fashion than with the wounds resulting from the cold blade ${ }^{16}$.

Another study ${ }^{7}$ comparing wound healing of incisions created by steel scalpel (with and without the application of $\mathrm{N}$-butyl-2-cyanoacrylate) and cryosurgery in tongue rats found that at day 7 , the specimens showing greater resolution of the acute inflammatory response were those belonging to scalpel and wounds caused by cryosurgery took the longest to reach any resolution of the acute inflammatory process. Showing that no matter the choice of cryosurgery ${ }^{7}$ or electrosurgery ${ }^{16}$ the use of cold blade leads to a faster resolution of the inflammation.

The results of this study are in agreement with those of the 1988 study $^{17}$. From the quality of proliferation of the epithelial tissue, there was seen to be less proliferation in the electrosurgery group at 3 days of evaluation than in the cold blade group. Although there was no statistically significant difference, a delay in cicatrization was clearly observed. 
Good results may be achieved when the use of electrosurgery is limited to the surface tissues and acceptable clinical techniques are used. However, undesirable cicatricial reactions, including necrosis of the surface tissues and sequestration of the alveolar bone, may be reported in intra-oral incisions. These reactions are attributed to an excessive accumulation of heat during the surgical procedure ${ }^{13}$.

A thorough understanding of each type of current, its therapeutic properties and correct use may prevent the emergence of possible lesions. The correct association of the active electrodes with the different types of current is fundamental to obtaining good results, since these factors, when not controlled, may interfere with the process of tissue repair.

Electrosurgery will never completely replace the cold blade, but although the former requires greater knowledge and skill, its benefits outnumber its shortcomings. If the clinical electrosurgical procedures and the laboratory techniques are applied in accordance with the recommended principles, electrosurgery will certainly be of great value in clinical dentistry.

\section{Conclusion}

There were no statistically significant differences between electrosurgery and the cold blade in relation to angiogenesis, fibroblastic proliferation, epithelial proliferation or the presence of inflammatory cells at any time of evaluation.

\section{References}

1. Sacot NJ, Peña CA, Pepe DA. Electrocirugia. Rev Fac Odontol. 1996;16(43):34-42.

2. Flocken JE. Electrosurgical management of soft tissues and restorative dentistry. Dent Clin North Am. 1980;24(2):247-69.

3. Sachs M, Sudermann H. History of surgical instruments: 7. The first electrosurgical instruments: galvanic cauterization and electric cutting snare. Zentralbl Chir. 1998;123(8):950-4
4. Camacho-Alonso F, López-Jornet P. Clinical-pathological study of the healing of wounds provoked on the dorso-lingual mucosa in 186 albino rats. Otolaryngol Head Neck Surg. 2007;;136(1):119-24.

5. Advincula AP, Wang K. The evolutionary state of electrosurgery: where are we now? Curr Opin Obstet Gynecol. 2008;20(4):353-8.

6 . Richter GT, Willging JP. Suction cautery and electrosurgical risks in otolaryngology. Int J Pediatr Otorhinolaryngol. 2008;72(7):1013-21.

7. Camacho-Alonso F, López-Jornet P, Bermejo-Fenoll A. Effects of scalpel (with and without tissue adhesive) and cryosurgery on wound healing in rat tongues. Oral Surg Oral Med Oral Pathol Oral Radiol Endod. 2005;100(3):e58-63.

8. Pollack SV, Carruthers A, Grekin RC. The history of electrosurgery. Dermatol Surg. 2000;26(10):904-8.

9. Kalkwarf KL, Krejci RF, Edison AR, Reinhardt RA. Subjacent heat production during tissue excision with electrosurgery. J Oral Maxillofac Surg. 1983;41(10):653-7.

10. Kaminer R, Liebow C, Margarone JE 3rt, Zambon JJ. Bacteremia following laser and conventional surgery in hamsters. J Oral Maxillofac Surg. 1990;48(1):45-8.

11. Krejci RF, Kalkwarf KL, Krause-Hohenstein U. Electrosurgery a biological approach. J Clin Periodontol. 1987;14(10):557-63.

12. D'Arcangelo C, Di Nardo Di Maio F, Prosperi GD, Conte E, Baldi M, Caputi S. A preliminary study of healing of diode laser versus scalpel incisions in rat oral tissue: a comparison of clinical, histological, and immunohistochemical results. Oral Surg Oral Med Oral Pathol Oral Radiol Endod. 2007;103(6):764-73.

13. Hall HD, Williams VD. Exaggerated tissue response to electrosurgery. Gen Dent. 1988;36(4):303-5.

14. Migliorisi JA. La electrocirugía en cirugía buco maxilar. Rev Odontol Urug. 1984;34(1):19-27.

15. Kalkwarf KL, Krejci RF, Schaw DH, Edison AR. Histologic evaluation of gingival response to an electrosurgical blade. J Oral Maxillofac Surg. 1987;45(8):671-4

16. Charbeneau TD, Stephenson LH. Severe destruction of the periodontium following electrosurgery. Gen Dent. 1988;36(2):135-8.

17. Gnanasekhar JD, Al-Duwairi,YS. Electrosurgery in dentistry. Quintessence Int. 1998;29(10):649-54.

Conflict of interest: none Financial source: none

\section{Correspondence:}

Prof. Dr. Belmiro Cavalcante do Egito Vasconcelos

Faculdade de Odontologia de Pernambuco (FOP/UFPE)

Disciplina de Cirurgia e Traumatologia Buco-Maxilo-Facial

Av. Gal. Newton Cavalcanti, 1650

54753-220 Camaragibe - PE Brazil

Phone/Fax: (55 81)3458-2867

belmiro@pesquisador.cnpq.br

Received: March 04, 2009

Review: May 06, 2009

Accepted: June 10, 2009

\section{How to cite this article}

Vasconcelos BCE, Freitas LHM, Santos LKM, Pereira JRD, Frota R, Porto GG. Comparison between eletrosurgery and cold blade in tongues of rats. A preliminary experimental study. Acta Cir Bras. [serial on the Internet] 2009 Sept-Oct;24(5). Available from URL: http://www.scielo.br/acb

*Color figures available from www.scielo.br/acb 